\title{
ELECTRONIC SPACES AS AN ALTERNATIVE TO TRADITIONAL CLASSROOM DISCUSSION AND WRITING IN SECONDARY ENGLISH CLASSROOMS
}

\author{
Sangmin Lee \\ Woosong University, Korea
}

\begin{abstract}
In most secondary school classrooms, teachers are still authoritative, central-figures. They talk and teach while students listen and passively receive what the teacher says. Regarding writing, the situation is similar. Students write only to the teacher, the person who grades their papers. In this environment, classroom dynamics are monologic and learning is limited to individuals. To establish a more constructivist learning environment, this study explored electronic spaces as alternatives to classroom dialogue and writing. This paper observed two 10th grade English classrooms (51 students) who participated in an exploration of Lord of the Flies using an electronic discussion board through which they collaboratively constructed knowledge. In short, the discussion board facilitated both studentcentered dialogues and an authentic writing environment, which promoted a dynamic learning community and healthy writer's identity for the students. Three salient features of the discussion board activity will be explored to support this claim: a) the students' use of questions and hypothetical/conditional sentences, b) the students' interaction patterns, and c) the dialogic/progressive patterns of co-construction of knowledge on the discussion board.
\end{abstract}

\section{KEYWORDS}

Constructivism, Discussion Boards, Student-Centered Learning, Writing

\section{INTRODUCTION}

In many ways, today's classrooms in secondary schools are characterized by monologues. In traditional approaches, the teacher is often the central figure in the classroom, as well as the most legitimate speaker. When writing, students write only to the teacher. All the buzz-words, such as student-centered classrooms, collaborative learning, and constructivist learning environments, still feel like remote goals in many classrooms, particularly where transmission models of lecture-based instruction are still prevalent. In this environment with the teacher as the central figure, the classroom practices are more like monologues rather than dialogues and depend heavily on what the teacher says. As Cooper noted, "The traditional forums comprising these classrooms... generally support a traditional hegemony in which teachers determine appropriate and inappropriate discourse" [1]. While monologues are more context-independent and less interaction focused, dialogues focus on interaction, communication, participation, and co-construction of meaning [2]. Therefore, in classroom environments in which instruction depends greatly on teacher-centered monologues and textbooks, students are often excluded from the dialogues. In this environment, there is not much space for students to generate and negotiate meaning.

Dialogue is essential to language classrooms in several ways. It provides students with authentic opportunities to use language in context within the school community [3, 4, 5]. From a Vygotskyian 
perspective, learning greatly depends on social interactions, and meaning is constructed through the process of transforming inner speech into public speech. The presupposition underlying this perspective is that participants interact by articulating their ideas, either spoken or written [6, 7]. Articulation makes thinking visible, public, and explicit, which is a critical aspect of learning [2]. Students' active participation in classroom dialogues can also more effectively promote student-centered classrooms [8]. Likewise, successful collaboration in learning is also profoundly dependent on the use of language [3]. However, the dynamics and power structures embedded in current classrooms often hinder student-centered dialogue [9, 10]. Even in the classrooms in which the teacher supports student-centered learning, the physical presence of the teacher can still be intimidating to the students, so that they are not willing to participate in classroom dialogues. Even when the students talk, they often talk only to the teacher, rather than to other classmates, so that the interactivity of discussions is diminished. Also, due to other variables, such as personality, perceived ability differences, time constraints, and lack of motivation, students often do not engage in classroom dialogues. In contrast, in classrooms where teachers and students are actively engaged in conversation, more opportunities exist for students to construct knowledge, face multiple perspectives, and reflect on alternatives.

Writing, like most classroom discussions led by the teacher, can also be a monologue. Typically, teachercentered classroom writing contexts create a double dilemma for students as readers and writers. As readers, students are positioned by the discourse of textbooks. As writers, since students normally write only to the teacher, students are positioned as inferior in relation to the power discourse of the classroom [11]. That is, the students write to the teacher, who is presumed to know everything and students thus often feel that they do not contribute anything to the reader's (in this case the teacher's) construction of knowledge. Moreover, the teacher is their grader and evaluator, thus, in this situation, student-writers do not feel they have any power, which leads to difficulties in establishing a healthy writer's identity or sense of authorship. Therefore, in this environment, almost everything is a monologue and learning is confined only to each individual.

The purpose of this paper is to identify the learning processes revealed in the online discussion board and how students learn and construct knowledge collaboratively rather than individually. It may provide teachers with insights on how to implement an online discussion boards in classrooms to support a constructivist learning environment. This paper will examine how an online discussion board was used in high school English classrooms as an alternative way of facilitating student-centered dialogue and writing as a means to mitigate the difficulties of classrooms described earlier. Two $10^{\text {th }}$ grade English classrooms used an online discussion board three times throughout the school year as a supplementary activity to more traditional in-class activities. The purpose of using the discussion board in these English classrooms was to provide the students with an opportunity to engage in different kinds of literacy practices and classroom dialogue experiences than their usual formal essay writing experiences and teacher-centered classroom monologues. In many other writing situations, the students normally produced isolated pieces of writing (one-time, closed writing), in terms of both interactions among themselves and continuation of ideas and knowledge about literature. On the discussion board, on the other hand, the students shared their perspectives on the book, Lord of the Flies, co-constructing and accumulating knowledge. In other words, the discussion board was a shared space as well as a writing space, which promoted collaborative learning among students. Technology encouraged interactions among the students, and concomitantly, it promoted collaborative learning, which, in turn, naturally facilitated the creation of a collaborative learning community. The process of discussion, debating, persuading, defending, criticizing, and arguing with other students on the discussion board was an opportunity for the students to articulate their inner thoughts and make them clear, explicit, and public. Thus, responding to others' ideas on the discussion board was expected to promote the students' writing to become more original and authentic. Finally, it was anticipated that sharing ideas about the novel on the discussion board would encourage multiple and alternative perspectives and broaden knowledge about the book. 
Therefore, on the discussion board, instead of writing individual essays about the novel to their teacher, they were actually engaged in a dialogue through writing, and they built their knowledge through interacting with others. Hence, writing on the discussion board was never a solitary act; it was a dialogic communication and sharing among the students. In short, the activities described in this study were authentic and furnished a "functional learning environment" to recontextualize the decontextualized knowledge and writing experiences [12].

\section{LITERATURE REVIEW}

As a communication and writing space, a discussion board can provide opportunities to explore a new medium, express ideas to a real audience, and meet multiple and alternative views. To date, a large number of studies have reported many benefits of discussion boards in learning. Laurillard noted that the online forum enabled teacher-student and student-student dialogue that led to increased discussion, interaction, and reflection, while motivating students and enhancing the flexibility of learning [13]. Furthermore, a discussion board can help students' articulation of inner speech become more visible and clear [14, 15]. It is also reported that online conferencing fostered in-depth discussion and promoted reflective and critical thinking [16, 17].

A number of previous studies also concluded that asynchronous discussion can facilitate collaboration and interaction between students and teachers and among students, even beyond classrooms [18, 19, 20]. Harasim referred to online discussion as "an augmented environment for collaborative learning and teaching giving learners flexibility, choice and freedom and enabling divergent thinking through idea generation" [21]. Bober and Dennen and Arnseth and Solheim also noted that online discussion helped students to share knowledge by developing shared ground and intersubjectivity among the participants [22, 23]. Hiltz argued as well that online conferencing could support interpersonal exchange, which led students to engage in the social construction of knowledge [24]. Carlson contended that computerized writing environments can improve the quality of writing by bridging the gap between thinking (process) and writing (product) [25].

In addition, numerous studies support the positive relationship between learning and learning community[17, 26, 27, 28, 29]. Scardamalia and Bereiter weighed the importance of community in learning, viewing knowledge building as a progressive of production, creation, improvement, and innovation of ideas in a given community [30]. Garrison also pointed out the significance of the shared world, as well as of personal responsibility in the learning process in which meaning is constructed [31]. In his study on the relationship between the students' interaction and performance in online learning, Picciano discovered that communities of inquiry, communities of learners, and knowledge-building communities evolved over a given period [32]. Benefits of asynchronous discussion also include more active and equal participation by the students [1, 33, 34, 35, 36]; more time to reflect on others' postings and their own before posting [37]; and better opportunities to engage in multiple viewpoints regarding on-going topics [1, 5, 15, 38, 39]. In sum, electronic discussion boards may encourage students' engagement, reflection, and inquiry, and promote ownership of their learning.

\section{METHODOLOGY}

\section{A. Data Collection}

This paper observed two $10^{\text {th }}$ grade English classes with one English teacher, 51 students in total, in a high school located in central Pennsylvania during the school year of 2003-2004. There were 19 males and 32 females. There were no ESL students in either class. The teacher's survey given before the activity confirmed that all the students had computers and the Internet service at home. 
The major data for this study were the students' messages on the discussion board. Among three discussion board activities, this paper specifically focuses on the one embedded in Lord of the Flies unit. The students were asked to post at least four messages during 6 weeks and everyone fulfilled the requirement. For this activity, a free discussion board site (www.worldcrossing.com) was used. This site allowed the students to have threaded discussions based upon the initiated postings, so that the students could easily follow the ongoing discussion, and not get lost in the middle of postings. The discussion board technically allowed the students to respond to specific previous messages, so that their replies automatically and graphically appeared as a discussion thread. It also provided the teacher with administrative functions, such as editing and deleting messages. On the discussion board, the novel was divided into five parts; parts 1- 3 were based on chapters and parts were added for Symbol and Mob Mentality. Part 1 was comprised of 68 messages; part 2, 56 messages; part 3, 54 messages; Symbolism, 32 messages; and Mob Mentality, 5 messages, so in total there were 215 messages posted during the six weeks of the activity. The students posted 16 topics and these topics included savagery, symbolism, plane crash, characters, rules and society, and patterns shown in the novel.

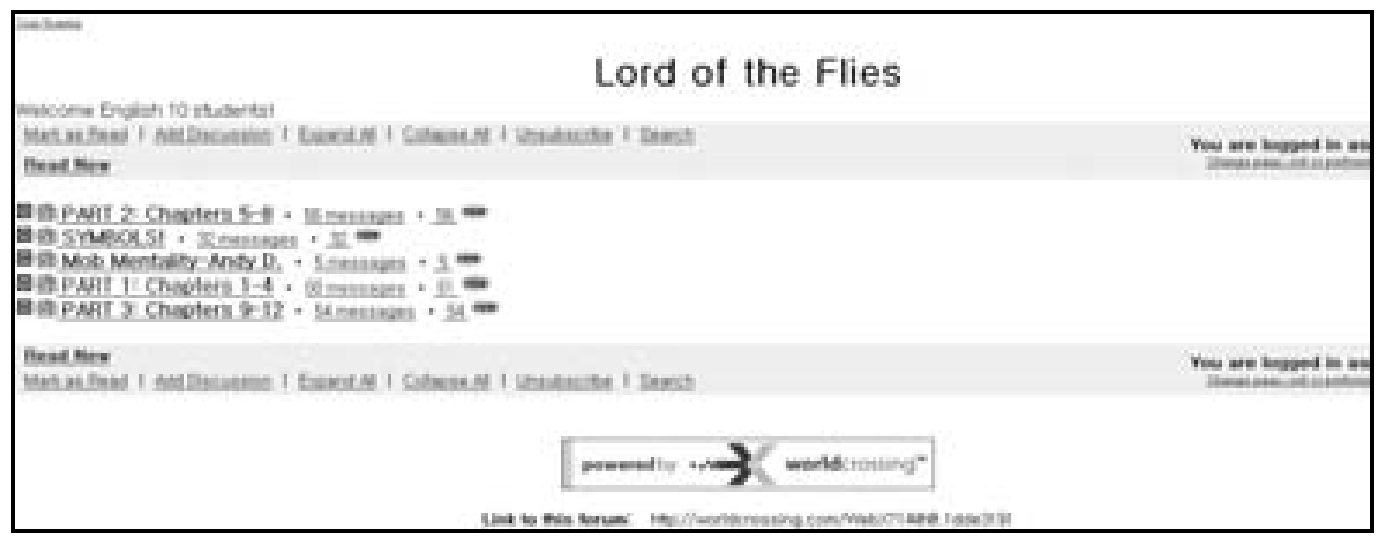

Figure 1: The Index Page of the Discussion Board from the Student's View

For a more holistic picture of the classroom dynamics, in-class observation was conducted through the entire school year, four times a week. Observation enabled the researcher to look at how online discussions and in-class discussions interacted with and influenced each other. Observations were recorded in field notes. In-depth interviews, interwoven with observations, provided more detailed information about the data and also served to cross-check the data gathered in observations, enhancing the internal validity of the data. One hour interviews were conducted during and after the activity with 16 students (twice each) and the teacher (four times). The interviews were open-ended, unstructured, audio-recorded and later transcribed. The students were interviewed in pairs, which helped elicit the students' perspectives and voices about the activity without much interruption from the interviewer. At the end of the activity a questionnaire was also distributed. While interviews were limited to a relatively small number of the students, the questionnaire provided a larger view of the phenomena under study, since it included a larger number of the students (51 students and a return rate of $100 \%$ ) as well as more questions inquiring about the topic of this paper. The questionnaire included questions about computer and Internet availability at home, their reading rate of messages posted by others, and reasons they liked (or did not like) the discussion board. In addition, the students had a one-hour in-class discussion to share their experiences about the discussion board.

\section{B. Data Analysis}

In this study, both qualitative and quantitative methods were employed to complement and support each other. Since there were multiple ways to look at the data, such as a micro or macro analysis, multiple units of analysis were considered at three different levels of analyses serving different purposes. At Level 1, the 
sentence level, each sentence was categorized based on types of sentences, such as questions, hypothetical/conditional sentences, and statements. At Level 2, interactions among the messages were mapped out, such as explicit/implicit replies and agreement/disagreement with previous messages, and who responded to whom. At Level 3, the message level, each message was grouped according to cognitive interactions. At this level, not only the message, but also the thought (meaning implication unit) in each message was taken into account, since a number of messages contained more than one meaning implication or function ("phase"). At this level, messages were taken as a unit of analysis rather than each sentence being analyzed, because the individual sentences in each message did not stand alone as a unit of meaning; instead, each message provided a more consistent, unified, and thematic picture of the students' intentions in the message. Also, instead of each message being broken into thought units, phases were further divided to fit each message. All three levels of analyses were used to analyze the following three features of the discussion board respectively: a) the students' use of questions and hypothetical/conditional sentences, b) the students' interaction patterns, and c) the dialogic/progressive patterns of co-construction of knowledge on the discussion board.

\section{FINDINGS}

\section{A. Feature 1: Questions and Hypothetical/Conditional Sentences}

One of the remarkable features of the discussion board was the high frequency of questions and hypothetical/conditional sentences. Questions were signed by a question mark, and hypothetical/conditional sentences were identified as those which contained "if (-then)," "whether," "would," "might," "could," "perhaps," "maybe," and "probably" [39]. Among a total of 215 messages on the Lord of the Flies discussion board, there were: 57 (27.4\%) messages containing questions; 38 (18.3\%) hypothetical/ conditional sentences; 6 (2.9\%) messages contained both question and hypothetical/conditional sentences; and $9(4.3 \%)$ messages were comprised of question-type sentences, which did not actually include a question mark, but in terms of their contents, should be considered as questions (such as in "I am wondering if Jack really wants to...”). Therefore, four types of sentences comprised 110 (52.9 \%) messages.

Both questions and hypothetical/conditional sentences served the same purpose on the discussion boardtriggering the students' inquiry and reflection and initiating further discussion. These often led students to in-depth discussions and multiple and divergent patterns of thinking. On this discussion board, 44 discussion threads were initiated where six large themes and 14 sub-themes were explored. All of the discussion threads, except for two, were initiated by student-generated questions (21 messages), hypothetical/conditional sentences (6 messages), a combination of question and hypothetical/conditional sentences (8 messages), or invitations by other students at the end of the messages after their speculations (question-type sentences-3 messages). Considering that the inquiry cycle begins with questions, these results were not unexpected [40]. Besides, the first messages in each discussion thread frequently included such words as "interesting," "confusing," and "curious," which showed the initial driving force of the students' inquiry and reflection started from "a state of perplex, hesitation, and doubt” [41].

Once their thoughts were provoked, the students built and rebuilt meaning upon one another's messages. Consequently, questions and hypothetical/conditional sentences were frequently expressed through inference and reasoning about issues, generating discussion threads. Hypothetical/conditional sentences were employed not only in triggering messages, but also in making inferences and judgments to pose and explore other possibilities and redirect and rebuild the on-going argument. As in the following example, the students added and advanced their ideas by hypothesizing the situation in the novel and imagining and posing different conditions of the situations. 
(In the abbreviated example below, question and conditional sentences are highlighted with bold font. The entire messages will be shown in the appendix. The numbers refer to the sequence numbers of the messages in the thread.)

Example 1:

1: If the boys hadn't become bloody thirsty, ... if they didn't hunt him... if there was no fire... if there is no savagery (then,) there would have been no rescue.

2: Even if no savagery, they would have been rescued, because Ralph would keep fire going. This fire is different from the fire for killing and hunting, representing for civilization. But the rescue ship was a war ship. Then, "Is Golding trying to say all civilization have savagery in them?”

7: If it would have been older more mature men it is likely that they would NOT have acted in the same manner as the younger boys did.

The high frequency of questions and hypothetical/conditional sentences on the discussion board compared both with those in writing in other situations and in-class discussions was highly related to the students' awareness and expectations of interactions with others and of responses from others about their inquiries. Based on the classroom observations in this study throughout the entire school year, questions and hypothetical/conditional sentences were found far less frequently in more traditional writing situations than on the discussion board. Because most of the classroom writings were meant to be unidirectional, that is, from the student to the teacher, there was not much interaction between the teacher and the students or among the students; thus, their writings were usually more conclusive and exclusive rather than questioning, hypothetical, or inclusive. While two other writing assignments (literary analysis and research analysis about different novels) were examined, there was no question asking for opinions or an invitation for the thoughts of others in the students' writings, and hypothetical/conditional sentences were rarely found. Even when these sentences were used, they were meant to draw conclusions, not to pose wonder or curiosity or provoke others' thoughts; therefore, there was not any interaction.

Similarly, it is significant that in classroom observations, questions and hypothetical/conditional sentences were not commonly found during in-class discussions. This was assumed to be mainly due to time constraints. Since the students had only limited time during in-class discussions, most of their questions tended to be confined to elementary clarification questions. In-depth clarification questions or hypothetical/conditional sentences, which normally required more time for reflection both from the questioners and the respondents, were not frequently generated. In this light, the feature of asynchronous communication, which allowed emancipation from time constraints, allowed the students more time for reflection before posting questions and inquiries on the discussion board, leading to in-depth questions about the issue [16]. The students in this study also reported in the interviews and questionnaire that freedom from time constraints was one of the great benefits of using the discussion board.

\section{B. Feature 2: Interaction Patterns}

Interaction patterns were analyzed to identify how the students constructed knowledge collaboratively and dialogically through their discussions and interactions on the discussion board, as opposed to individual learning or writing about the book. Replies to previous messages were 157 (75.5\%) messages, and 115 (55.3\%) messages were explicit replies to previous ones. Figure 2 shows the reply pattern of one of the discussion threads. This feature exhibits how actively the students replied to and interacted with others explicitly as well as implicitly. The arrows indicate only direct or explicit replies to previous messages. Due to the technical affordance of the discussion board site, while some messages were automatically marked as replies to the previous ones, others were not graphically marked as direct replies to previous messages. The latter cases could be either explicit or implicit replies to previous messages based on whether or not there were explicit lexical references to a previous message by the name of the student of the message. When 
there were no explicit references of previous messages, yet there was topical cohesiveness with previous messages, and those messages were grouped as implicit replies to previous ones. Hence, the threads were categorized according to topical cohesion, instead of technical grouping. Thirty-eight among 44 threads in total (86.3\%) actually formed discussion threads, and only 6 (one-message threads) messages were not replied to.

Overall, on the discussion board in this study, the students were highly interactively replying to others' messages, rather than producing and concentrating only on their own texts. Noticeably, their interactions and exchanges were surprisingly limited to the cognitive domain (focusing on sharing knowledge about literature), not the social domain; only one message was categorized into the social domain. As in Meyer's study, since this was a mixed-mode course where the students interacted both in class and online, they needed less prompting to post messages for social cues to build a community and maintain social and personal relationships online [42]. This meant that, for the most part, the students remained on task. Highly marked number of replies to others' messages, which stayed mostly on task, was additional evidence that the students were very interactive on the discussion board, which was a vital sign of the co-construction of knowledge and collaborative learning [43].

In addition, as will be shown in Figure 2, a high frequency of disagreement was another salient feature of the discussion. This was also another triggering factor to induce further discussion on the issue concerned. Among 115 explicit and direct replies to previous messages in all discussion threads, 30 messages (26\%) were explicit disagreement, while 14 messages (12.2\%) were explicit agreement with previous messages, that is, marked by explicit expression of their judgment by saying, "I agree (disagree) with you." The disagreement (also agreement) could be either total disagreement with previous messages or partial disagreement. Besides, since the students usually vacillated on the continuum of two positions under an issue with different degrees and variants, a disagreement with the message immediately prior to it often could be an agreement (or a partial agreement) with the remote previous messages. Similar to questions and hypothetical/conditional sentences, disagreement, rather than agreement, tended to provoke more arguments and generate longer messages $[44,45,46]$.

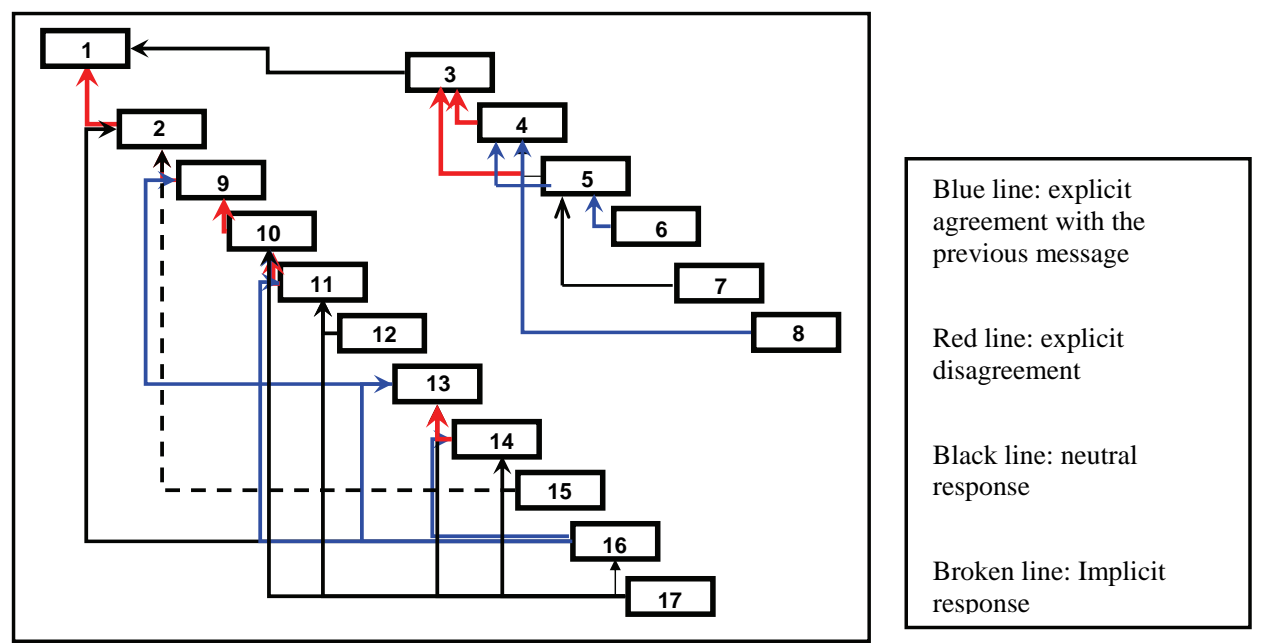

Figure 2: The Reply Pattern of Messages on the Discussion Board

The high frequency of disagreement on the discussion board was largely attributed to Computer-Mediated Communication; that is, the students did not see one another on the discussion board. Thus, unlike face-toface discussions, they felt more comfortable to criticize and to be criticized, as reported during the interviews and questionnaire, as also indicated in previous studies [1, 32, 38]. 
Electronic Spaces as an Alternative to Traditional Classroom Discussion and Writing in Secondary English Classrooms

\section{Feature 3: Dialogic Pattern of the Interactions}

We are still in the initial stages of Computer-Mediated Communication (CMC) in educational settings, and there is not a single best analytic model to fit all situations. Thus, as other researchers have developed and designed their own models to serve their data and situations more accurately, a new model was developed for more robust criteria to analyze the data in this study, based on Garrison's critical thinking model and Henri's content analysis model [44]. Garrison's model of community inquiry illustrates the logical sequence of the process of critical inquiry of the dialogic patterns of the interactions among the students. This model includes four phases of triggering, exploration, integration, and resolution [31]. Henri's analytic model of computer conferencing is comprised of five key dimensions (participative, social, interactive, cognitive, and metacognitive); this paper focuses on the cognitive and interactive dimensions, because they provide criteria for cognitive skill and the interactive process of the online discussion respectively.

These two models were used because 1) both models present social and cognitive processes of learning in online discussion forums; 2) both of them concentrate on the process of learning rather than outcome; 3) and they examined learning process both as collaborative and individual one. These features of the two models helped to develop a new model to analyze the data of the present paper.

\begin{tabular}{|l|l|l|l|}
\hline Phase & Description & Garrison & Henri \\
\hline Triggering & $\begin{array}{l}\text { Recognizing the problem, sense of puzzlement, } \\
\text { identifying relevant elements, describing the } \\
\text { subject matter, assumptions, establishing } \\
\text { referential criteria, and defining terms }\end{array}$ & $\begin{array}{l}\text { Triggering } \\
\text { (evocative) }\end{array}$ & $\begin{array}{l}\text { Elementary and } \\
\text { in-depth } \\
\text { clarification }\end{array}$ \\
\hline Inferencing & $\begin{array}{l}\text { Making generalizations, drawing conclusions, } \\
\text { formulating propositions, Convergence among } \\
\text { group members }\end{array}$ & $\begin{array}{l}\text { Exploration } \\
\text { (inquisitive) }\end{array}$ & Inferencing \\
\hline Judgment & $\begin{array}{l}\text { Judging the relevance of solutions and } \\
\text { inferences, such as “I agree, disagree...” }\end{array}$ & $\begin{array}{l}\text { Integration } \\
\text { (tentative) }\end{array}$ & Judgment \\
\hline Synthesis & Synthesizing two opposing positions & Integration & N/A \\
\hline Evaluation & Appreciation, evaluation of others' messages & $\begin{array}{l}\text { Resolution } \\
\text { (committed) }\end{array}$ & $\begin{array}{l}\text { Application of } \\
\text { strategies }\end{array}$ \\
\hline
\end{tabular}

Table 1: Interactive Phase Model

The discussion threads that started with triggering messages were generated from the students' inquiries. This phase consisted of two cognitive levels in Henri's model-elementary clarification and in-depth clarification; however, in this paper, these two levels were not differentiated. Both were categorized into the triggering phase, since the present study focused on the students' collaborative construction of knowledge on the discussion board, not on labeling their cognitive skills. Triggering messages appeared not only in the beginning of a discussion thread, but also in the middle. Among 76 messages categorized into triggering, 47 (61.8\%) were displayed in the middle, not in the beginning, of the discussion threads. (Considering there were 44 discussion threads, these numbers also indicate that 5 threads did not start with triggering messages. They were categorized into inferencing, but still provoked others' thoughts and initiated discussion.)

Earlier questions and hypothetical/conditional sentences functioned to trigger further discussion, with a high frequency of these types of sentences appearing in the middle of threads. This demonstrated that the students continuously added new ideas, triggering inquiry. While the students were exploring and developing the issues triggered, they continued to add more questions, pose new hypotheses, and give new perspectives on the issue. As shown in Table 3, among 114 messages in all four sentence types, 76 messages in total (66.7\%) were shown in the middle of discussion threads, not in the beginning. 
Electronic Spaces as an Alternative to Traditional Classroom Discussion and Writing in Secondary English Classrooms

\begin{tabular}{|l|c|c|c|c|}
\hline & Question & Hypothetical & Combination & Invitation \\
\hline In beginning & 21 & 6 & 8 & 3 \\
\hline In the middle & 36 & 32 & 2 & 6 \\
\hline In total & 57 & 38 & 10 & 9 \\
\hline
\end{tabular}

Table 2: Four Types of Sentences Shown on the Discussion Board

The judgment phase, equivalent with judgment in Henri's model and exploration phase in Garrison's, was usually built upon triggering messages. This phase included the students' information exchanges and judging the relevance of the claims in others' messages. Even though some in-depth clarification messages and of inferencing messages overlapped within this phase, only judgmental messages were categorized into this phase. Despite some exploring features, in-depth clarification messages generally functioned as triggering, and inferencing messages mainly served to integrate their knowledge about the book and the world from the ideas that appeared in others' messages. In this phase, their ideas and thoughts continued to develop to become divergent, expanding the questions and propositions with supporting evidence from the book. Hence, the students' judgments of others' messages were usually their opinions about the novel based upon and extended from inferences from the book or application of their previous knowledge. Thus, similar to the examples below, messages containing "I agree" and "I disagree" were categorized as a judgment phase. (Words in bold: question/hypothesis in, sentence-level analysis, Feature Analysis 1; underlined: judgment in, interactive pattern analysis, Feature Analysis 3).

Example 2:

1. Ralph /Chess : I think Ralph notices a lot of people in the group starting to follow Jack instead of himself, which leads to all the blaming that Ralph places upon Jack. Based upon this you could say that Ralph is a bad leader and a bad strategist. A strategy is based on a decision and decisions are what make a terrible or great leader. It is clear that Ralph did not think over all of his decisions. If he did, wouldn't he still have control over the group?

2. Ralph, a good leader?: I agree, but I also think that it was not really under Ralph's power to have control over the group. Jack and his hunters are pretty outgoing and Ralph seems to be a little more quiet, except he seems like he couldn't say anything he never meant. I think Ralph didn't want to give in because he wanted rescued so badly. If someone like Piggy was the leader then they could have probably kept their power over the group by giving in to hunting all the time and letting Jack and the hunters do as they pleased... then again, maybe this would have made things more complicated and he would have lost control anyways. All in all I think Jack and his hunters wanted more freedom and Ralph refused to give them that.

No. 1 raised a new issue on Ralph as a leader, by posing a question at the end of the message. No. 2, a response to No. 1, started with agreement, but the agreement was immediately followed by another interpretation of the issue and the ideas became divergent through more hypotheses about the issue.

The integration phase was defined as the convergence of ideas and this phase was further divided into inferencing and synthesis in this study. Inferencing was marked by connecting ideas, induction and deduction from the previous messages and their previous knowledge, integrating information from various sources, and linking and structuring their ideas. Inferencing was often employed to enhance their ideas, develop or support their claims and argument further, or find evidences to warrant their judgments of others' messages (bold: question/hypothesis; italic, replies to previous messages; underlined, interactive phase).

Example 3:

10. yes the paint. I agree that it "gives them a false sense that other people cannot see who they are or what they are doing." that was well said. 
that happens in many situations in real life too. feeling at liberty to be something else when you're under a new identity...or maybe not acting, just letting your true self come out... I think so many people at some point in time wonder what it would like to be someone else, or to at least be different in some way. Wearing masks or putting on a uniform makes people feel enabled to be someone else (sometimes in great ways, sometimes in subtle ways), or to act in a different way. I'm not saying that the boys who had the paint were acting like the person they wanted to, just thinking about the whole concept of masks.

That leads me to another thing--were the boys with the paint acting the way they wanted to? I wonder what they would do if they put on paint when not on the island...how would they change then... I find it hard to think they all "wanted" to act in such violent ways...but then again-I suppose they didn't all want to....I don't know. I'm going to stop now.

The message above indicated that it was a reply to the previous message by repeating what was said in the previous one ("gives them a false sense that other people cannot see..." in italics) and displaying her agreement with it ("yes," and "I agree"). The second paragraph demonstrated how she integrated the issue of paint raised in the previous message with her knowledge about the world and how she expanded the issue (the underlined part). Integrating others' ideas with her own also led her to more inquiry and posed a new question to others (her triggering sentence is marked by "wonder," indicated by underlined), again, by hypothesizing a situation different from the situation set up in the novel (in bold).

Whereas integration defined by Garrison et al. included the messages integrating others' ideas followed by substantial agreement, such as, "I agree...," treating the term as an indicator of integration and considered as synthesis, in this study these were categorized into judgment, not as integration or synthesis [31]. The reason for this is that in many cases, the messages containing agreement were only partial agreement with previous messages and the ideas about the topic were still divergent, thus, these messages were not categorized into integration. Hence, synthesis in this study included only messages synthesizing different ideas and perspectives, sometimes two opposing positions, under one issue, rather than integrating the ideas from the same perspectives. The following is an example of synthesis as defined in the present study.

Example 4:

16. Our small group discussed the possibility that Piggy represented three things:

a. Intellect-Piggy came to the island with the innate ability to both think and rationalize easily and clearly. The others both resented and/or feared this gift.

b. Democracy-Piggy was the most ardent advocate of the conch, which in turn was itself a symbol for a society in which each person has the right to speak or add an idea. Through his actions, Piggy emphasized both fairness and order.

c. Reality-This was the product of an intense discussion. In the end, Larissa came to the conclusion that it was Piggy that brought everyone else back to the reality of their situation. Even Ralph refused to see their plight for what it was, but from the very beginning, Piggy made no bones about their future. On page 14, in first meeting Ralph, Piggy said “They're all dead...an' this is an island. Nobody don't know we're here. Your dad don't know, nobody don't know...” The glasses also tied into this, because Piggy had the ability to SEE the facts for what they were... We were able to link several other symbols to this idea, all of which are available in our group notes. In any case, we theorized that it was the fact that Piggy refused to let the other boys dream away their problems that most caused their ill treatment toward him. We were also able to relate this to our real lives. No matter how logical they are, people who bring us to see the truth, often unpleasant, are frustrating. It was a very exciting revelation!

This message was categorized into synthesis because all three issues she illustrated in the example above were already mentioned in other previous messages; thus, in her message, she synthesized and summarized 
the ideas about what Piggy represented and integrated ideas within her own message from the in-class discussion and previous messages. Even though this message functioned as synthesis, it did not terminate the discussion; rather, it triggered more thoughts following. Thus, it was synthesis and at the same time, triggering. This cycle was often repeated, instead of occurring in a one-time cycle. It was also found in this study that the exploration phase and the integration phase were not necessarily hierarchical or sequential; rather, they overlapped and were iterative.

For the last phase, evaluation was added in place of resolution in Garrison's model, equivalent to the application of strategies in Henri's model. Application of strategies and making further decisions related to the real-world, which both scholars considered as indicators of the last phase, were not found in the present study. Instead, this phase included the students' evaluations and appreciations about the book and others' ideas on the discussion board, such as "That was an excellent point!" "PA! Revelation is an exact word," "a good question," "a nice idea," and "a relevant argument about the issue." These comments were differentiated from the messages with "I agree."

The phases in Table 1, therefore, were sequential, as well as hierarchical, to show the progress of the construction of dialogue, interaction, and knowledge among the students. They were also cyclic and recursive, not a one-cycle progress. Thus, even though the phases were sequential, that does not mean that they were strictly serialized; rather, after the triggering phases, any of the phases could follow and those phases were repeated. For instance, triggering messages often followed after exploration (either inferencing or judgment). Furthermore, categorizing the messages into each phase was not always clean-cut. As shown in Table 2, the messages frequently contained more than one phase. For example, the students started a new message thread with inference from the novel or their reading experiences with the novel and closed the message with invitations to others to the discussion, which functioned as triggering. In other cases, the students began a message with judgment about a previous message, and then continued inferencing to explain about the ground of their judgment or to develop the issue further as an extension of the previous messages. Therefore, shown in the Table 3 below each message was categorized by only one dominant phase or combination of two phases.

\begin{tabular}{|c|c|c|c|c|c|c|c|c|c|}
\hline Phase & $\exists$ & $\exists$ & & $\infty$ & Con & tions of & & & Z \\
\hline Theme & 蛋. & $\underset{\Xi}{\stackrel{\Xi}{\Xi}}$ & $\stackrel{\overparen{D}}{\mathrm{D}}$ & 点. & 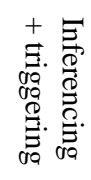 & 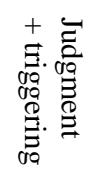 & 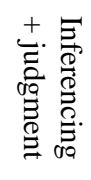 & 节. & \\
\hline Leadership & 16 & 17 & 8 & 1 & 0 & 0 & 3 & 0 & 1 \\
\hline Savagery & 6 & 10 & 3 & 1 & 3 & 0 & 4 & 0 & 1 \\
\hline Plane Crash & 2 & 1 & 2 & 0 & 0 & 1 & 0 & 0 & 0 \\
\hline Patterns/Styles & 1 & 0 & 3 & 0 & 3 & 2 & 0 & 0 & 0 \\
\hline Characters & 17 & 18 & 9 & 1 & 2 & 2 & 9 & 3 & 1 \\
\hline Symbolism & 11 & 21 & 5 & 3 & 4 & 5 & 1 & 0 & 0 \\
\hline Miscellaneous & 3 & 1 & 0 & 0 & 0 & 0 & 0 & 0 & 1 \\
\hline Total & 54 & 68 & 32 & 6 & 12 & 10 & 17 & 3 & 4 \\
\hline
\end{tabular}

Table 3: Thematic Threads and Interactive Phases

Figure 3 shows how the messages spread across the phases, which also provides a glimpse of how the students actively responded to one another and collaboratively constructed knowledge through their written interactions. 
Except for those in the triggering and N/A categories, the messages in the other categories were actually built upon the previous messages. Even in the triggering category, only 21 of the 54 messages initiated a new discussion topic; the remaining 33 were embedded in replies within one of the discussion threads.

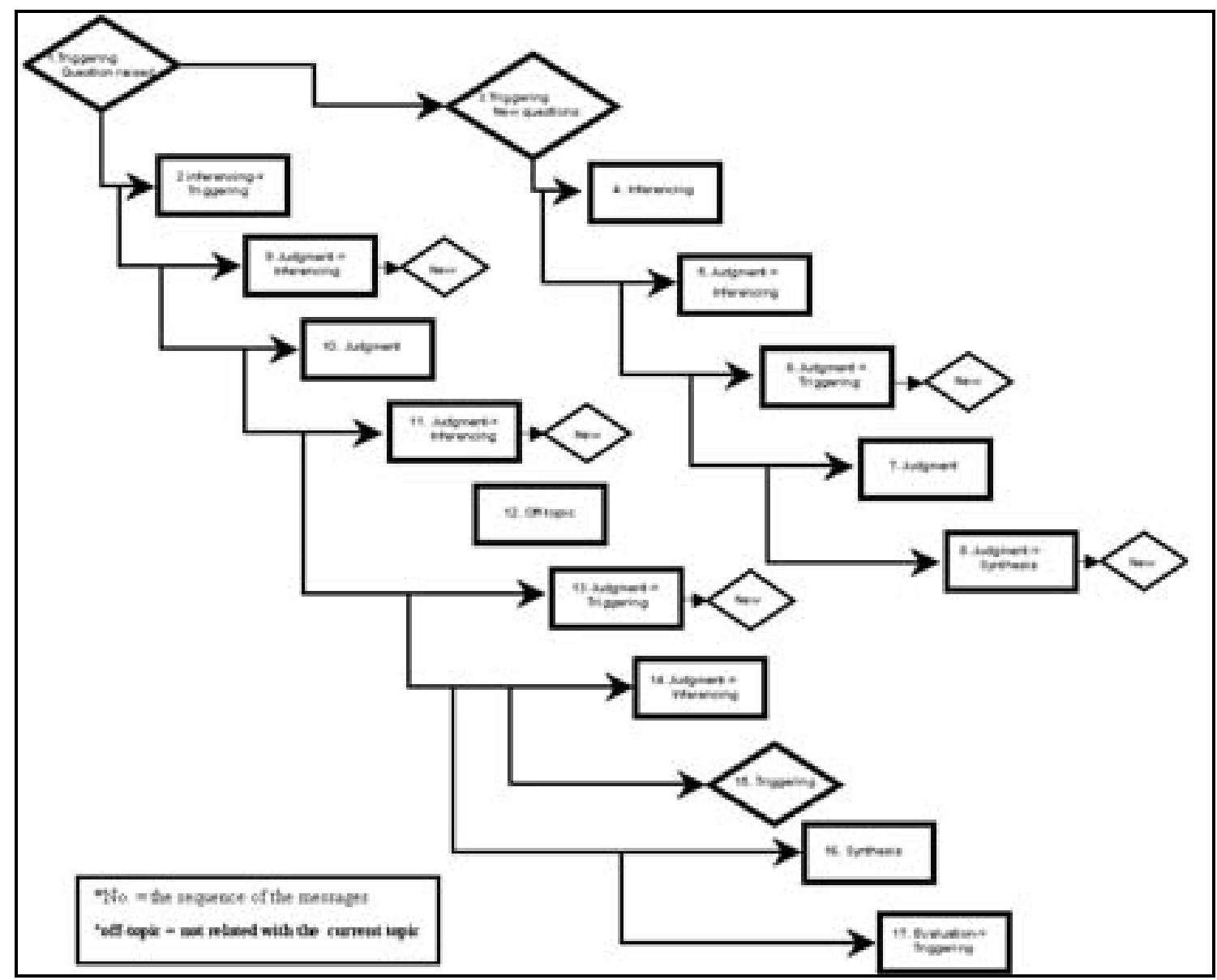

Figure 3: The Dialogic Pattern of the Construction of Knowledge on the Discussion Board

Hence, students' inferencing or judgment could be "triggering” to others and they built and constructed on others' inferencing, hypothesis, exploration and tentative conclusion until the ideas were exhausted or wrapped up and another topic was initiated. The ideas moving both back and forth, therefore, should be taken as a progression of the process of knowledge building. Between the two opposite views, moving back and forth, "back" should not be considered as regression of the ideas; rather, all the ideas were progressive, moving toward the synthesis, in what Wells called "progressive discourse" [15]. As shown in Figure 3, through this progressive discourse, the students constantly negotiated meanings and constructed knowledge, like Langston's metaphor of writing in electronic spaces, "a precipitating solid in a supersaturated solution, essentially the speck of dust around which crystals form" [47]. Thus, through the active process of exploring the issue, comparing and sharing their perspectives with others, clarifying dissonance, and reaching communal knowledge, the students understood others' perspectives as well as made their own perspective understood by others. 


\section{DISCUSSION}

\section{A. Learning Community}

During the discussion board activity, electronic spaces promoted a learning community among the students where they shared their knowledge and perspectives about the book and accumulated knowledge through writing online. Instead of writing a literary essay on reading to their teacher, the students had a real audience and real purposes for writing. Therefore, they were actually engaged in an authentic writing and communication situation whose goal was sharing their thoughts and collaborative construction of knowledge through writing. The discussion board visibly displayed the evidence of how the students developed and maintained a learning community. The fact that 162 messages (75.4\%) among 215 messages in total were replies to previous messages indicated that the students were actively engaged in the learning community. This fact is also congruent with the questionnaire, in which the students responded that they read thoroughly $61.8 \%$ of the messages on the board (on average) and browsed most of them. As noted in the previous section, the discussion board also became a public shared knowledge space, where the students constructed and reconstructed knowledge on others' ideas, rather than simply accumulated monologic, individual writings. Besides, according to Campos, the logical construction of meaning through hypothesis and inferencing does not just reside within each person's message, but is also woven in collaboration through written discourse on the discussion board [45].

In addition to cognitive presence, Garrison et al. identified the awareness of social presence of themselves and others in the community as further evidence of a successful inquiry community [48]. In Table 4 below, the concepts of social presence are organized to describe the discussion board data findings.

\begin{tabular}{|l|l|l|l|}
\hline Category & Examples & Indicators & $\begin{array}{l}\text { No. shown in the } \\
\text { present data }\end{array}$ \\
\hline Emotional expression & $\begin{array}{l}\text { Self-disclosure } \\
\text { Social/emotional support }\end{array}$ & $\begin{array}{l}\text { Closeness, warmth, and } \\
\text { attraction }\end{array}$ & N/A \\
\hline Open communication & $\begin{array}{l}\text { Mutual awareness } \\
\text { Recognition of each other's } \\
\text { contribution }\end{array}$ & $\begin{array}{l}\text { Explicit expressing } \\
\text { appreciation and agreement }\end{array}$ & 26 messages (12.0\%) \\
\cline { 3 - 4 } & $\begin{array}{l}\text { Complimenting and } \\
\text { encouraging others }\end{array}$ & 28 messages (13.0\%) \\
\hline Group cohesion & $\begin{array}{l}\text { Sense of group commitment } \\
\text { (Participation rate) }\end{array}$ & Reply rate & 119 messages (75.5\%) \\
\cline { 3 - 4 } & Reading rate & $61.8 \%$ \\
\hline
\end{tabular}

Table 4: Social Presence (215 message in total)

As pointed out earlier, the interactions among the students in this study were nearly exclusively confined to cognitive exchanges because they also had face-to-face interactions in which they shared socio-emotional exchanges; thus, emotional expressions were not found in the data [43]. However, the other two categories of social presence, as well as inviting others' thoughts, questioning rigorously and responding actively to others, indicated that the students sensed themselves and others as members of the learning community [17]. In the open communication category, explicit expression of agreement and explicit complement of others were marked $12.0 \%$ and $13.0 \%$ respectively. Group cohesion refers to the students' awareness of themselves as members of a group rather than individuals. In group cohesion, the participation rate was employed to measure the sense of group commitment, and specifically in this study, participation rate was further divided into reply rate (75.5\%) and reading rate (61.8\%), both of which were markedly high. 
The questionnaire on the discussion board also revealed that this community valued sharing knowledge with others and learning from and about others' perspectives. To the question, "What did you like about the discussion board?" 40 students of the 51 students in total $(78.4 \%)$ listed as the primary benefit an opportunity of "sharing their opinions with others." Considering the question was an open question, this number was very significant. They answered; "easy to share opinions," "a good way to learn different perspectives," "provided a chance to meet many questions and ideas I hadn't thought of before," and "I like interaction with people." The questionnaire also indicated that the discussion board helped the students not only learn about themselves and from others, but also helped them articulate their ideas and thoughts with others more easily. They answered in the questionnaire that the discussion board also "allowed me to express my thoughts," or "helped me articulate my thoughts.” Remarkably, some students mentioned it was a comfortable and effective way for the shy students to voice their ideas, and concomitantly, by the same token, it was a great opportunity for others to listen from the shy classmates who were normally quiet in the class. Therefore, sharing with others on the discussion board benefited the students both as posters and as audiences. Thus, it is fair to say that all participants had equal access, equal opportunities, and made unrestricted contributions to the discussion board. Equal access and equal opportunities, in turn, led to more quantitative participation, which eventually, as the classroom teacher reported, contributed to better qualitative discussions [20]. Hence, electronic spaces during this activity allowed the students a greater diversity of perspectives and interpretations about literature, wherein the students, as members of the community, participated in and contributed to the knowledge-building community by collaboratively making sense of meaning, creating knowledge, and sharing and advancing ideas.

In doing so, the students needed to make themselves understood by others. Expanded from Vygotsky's notion, Wertsch argued that individuals do not "simply internalize and appropriate the consequences of activities on the social plane" [49]. Rather, "each individual, as an agent, through the dialectic and dynamic tension between the social (intermental) and individual (intramental) in the joint activity, each individual restructures knowledge" [49]. Therefore, not only agentive individuals, but also the learning community is essential to individuals transferring from the social plane to the internal plane, that is, learning. From this standpoint, the discussion board provided a space for the intramental plane and promoted this transfer by facilitating the opportunity to articulate ideas publicly and furnishing perspectives different from their own. Henri also put the value of CMC as its use of the written word which "demands exactness, coherent organization of thought, and clear, restrained and authentic expression” [44].

In this light, the discussion board activity functioned as an authentic learning situation that satisfied the values of the community. Considering that learning is not a separate, individual, and independent activity, but "an integral aspect of participation in any Community of Practice," the role of electronic spaces was never insignificant as an arena for sharing with and communication among the members within the community [15]. Hence, learning within a community helped the students realize that knowledge is not static or stable; rather, it is constantly evolving, dynamic, and changing through negotiations and renegotiations among the participants in the community. Thus, the individual did not own meaning and knowledge, but the whole community constructed knowledge collaboratively. In Myers' words, "Knowledge lives beyond an individual self" [51]. Electronic spaces in this study, by documenting participation, construction, and transformation, made the process of the social construction of knowledge among the participants more visible and transparent.

\section{B. Students' Writer's Self}

The students' sense of themselves as members of a learning community wherein they contributed to the construction of knowledge through writing, in turn, promoted students' authorship and identity as writers as well. As discussed earlier, students in the traditional classrooms are often positioned as inferior both as readers and writers. The discussion board activity described in this paper helped resolve this double- 
dilemma by providing an alternative way of writing. By sharing their understanding and knowledge with other classmates who had the same power status, the discussion board activity helped them feel empowered as authors. Also according to Montague, a collaborative writing environment helps students "view writing from a problem-solving perspective" (p. 43), and this facilitates their writing skill and promotes exchange of ideas among peers [52]. Teaseley and Roschelle also maintained that conversation is the process whereby participants collaboratively negotiate and construct a joint problem space [53]. During the discussion board activity, the entire process of triggering, exploring, and integrating their ideas on the discussion board was another problem solving situation through written communication. Rather than being assigned literary essays, through this problem-posing and problem-solving situation, the students became more active in participation in classroom dialogues and the collaborative construction of knowledge.

The strong sense of authorship also helped the students voice their positions and act as experts. In most traditional classrooms, students are treated as non-experts and passive recipients of knowledge [54]. On the other hand, during the activities in the present study, the main purpose was to share with others what they knew and felt about the book through writing. This sometimes required them to defend their positions in order to make themselves clear to others, which led to stronger voices in their writing. This was clearly shown in their frequent use of the first person pronoun and explicit agreement and disagreement as well as voicing strong argument on the discussion board.

Not only did the students consider themselves as experts and writers with stronger authorship, also they regarded their peers as learning resources. During the classroom discussions and during interviews, the students frequently referred to what they learned about the book from others. Peer references implied that they weighed their peers' opinions as authoritative resources, such as shown in the example below. (The number refers to the sequence number of the message in the discussion board.)

\section{Example 5:}

88. On page 22 the statement appears... This illustrates, as Yla said, that the boys....into the idea of "no grownups,” as DR phrased it, because...

Similarly, as explained earlier in this paper, awareness of social presence, such as questioning others, active interactions, and invitations of thoughts, is also evidence that they viewed their classmates as learning partners and knowledgeable peers as well as learning resources.

In conclusion, regarding both themselves and their peers as learning partners of equal status empowered the students as knowledge-producers and writers. The student role of expertise was possible due to shifting the power from the teacher to the students. Cooper and Selfe noted that electronic writing learning spaces reduced the dominance of the instructor and this, in turn, helped students resist the roles that school discourse normally placed on them and instead introduced their own perspectives and interpretation of the readings [1]. The discussion board activity described in this paper provided a unique writing opportunity to the students, which expanded their writing and communicating spaces. The collaborative process of the construction of knowledge through writing empowered each student and consolidated himself or herself as a writer by endowing each student more authority over his or her own writing, as well as the writing of their peers.

\section{The Discussion Board as a Situated Activity}

The discussion board was effectively incorporated into and complemented by in-class discussions so that students easily connected their discussions between online and offline discussions. Connecting in-class discussions and the discussion board, the discussion board further enabled the cycle of reflection and inquiry. 
The students utilized the discussion board for further clarification and inquiries after in-class discussion. For example, to the question about the color symbols used in Lord of the Flies, one student responded:

Example 6:

\section{Reply to color}

I know that we discussed this a lot today in our group discussion and I feel that Golding uses a lot of color symbolism, as well... [sic] (posted by ME).

The discussion board expanded the collaboration and co-construction of knowledge beyond the groups, allowing the students to share their groups' ideas. Beyond the groups, their ideas were shared across classes,

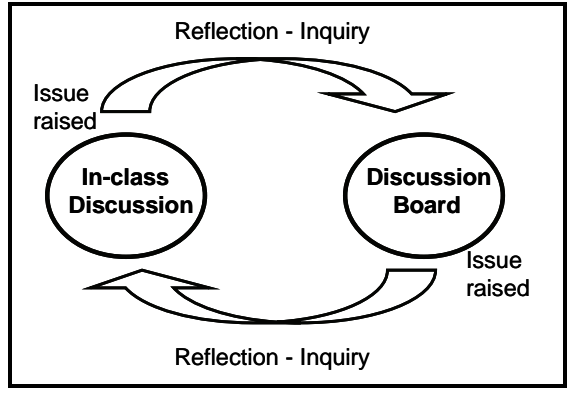

Figure 4 Inquiry-Reflection Cycle between In-class and the DB since the discussion board was shared by two classes. For example, to the question, "Is Golding trying to say something about family or companionship?" one of the students, who was in a different class posted her answer:

Example 7:

102. .....sic] In class today, we talked about how Lord of the Flies is Golding's way of describing how separated civilizations developed in the world... We also talked about how each of Golding's characters represented different types of people/groups in the world. Therefore, combining the world who shift loyalties a lot... [RM]

Not only did the discussion board bring issues raised in class that day, it also sparked in-class discussions the next day, as well as connecting with the previous in-class discussions. In this sense, again, the discussion board served as a space for both reflection and inquiry. When students still had confusion, conflicting views, or interesting issues and perspectives after discussing online, the students or the teacher brought them to the class the next day. In addition, they sometimes proposed ideas on the discussion board for further discussion in class, such as in "Let's talk about this in class tomorrow."

\section{CONCLUSION}

This paper presented evidence that the discussion board, as a writing and communicative space, offered the students opportunities to write collaboratively and share their ideas and thoughts. Instead of writing individual essays about the novel to their teacher, they were actually engaged in a dialogue. Writing on the discussion board was never a solitary act; it was a dialogic communication among the students. This dialogic characteristic greatly contributed to decentering the classroom, thus, empowering the students as authors. Through this dialogic writing process, the students generated their own inquiry-driven issues about the novel and negotiated meaning. This process was visually articulated and recorded on the discussion board. This sharing promoted the social construction of knowledge by exposing ideas and thoughts publicly to others. On the discussion board, the students' thoughts were subject to criticism. This feature, in conjunction with the distinctive features of asynchronous computer-mediated-communication, encouraged the students to voice their opinions [17].

By analyzing student interactions in an online discussion board in a blended learning environment this paper tried to give a glimpse into the learning process online, especially the process of the collaborative construction of knowledge. Examining student performance, perceived learning, satisfaction, and retention are topics worthy of future research. Although the researcher observed the classrooms throughout the school year, no systematic comparative studies between F2F and online learning environments have been 
conducted. Also, the role of the teacher as a facilitator in online discussion also will be another important topic for future research, as mere incorporation of online discussion boards would not have a significant effect on student learning.

\section{ACKNOWLEDGEMENTS}

I would like to thank Dr. Jamie Myers for his insightful guidance and support, without which, the publishing of this paper would not have been possible. I also owe a debt of gratitude to my colleagues at the Secondary English Professional Development School, State College Area School District and Pennsylvania State University (www.ed.psu.edu/englishpds) for their heartfelt support. I am especially grateful to Ms. Pangborn for supporting the collaboration reported in this paper.

\section{REFERENCES}

1. Cooper, M and C. Selfe. Computer Conference and Learning: Authority, Resistance, and Internally Persuasive Discourse. College English 52: 847-869, 1990.

2. Enyedy, N., P. Vahey and D. Gifford. Active and Supporting Computer-mediated Resources for Student-to-student Conversations. In: Hall, N. and N. Eneydy (eds.), Computer Support for Collaborative Learning, 27-46. Toronto: LEA, 1997.

3. Schrage, M. Shared Minds: The New Technologies of Collaboration. New York: Random House, 1990.

4. Gere, A. Writing Groups: History, Theory, and Implications, presented at College Composition and Communication. Carbondale, IL, 1987.

5. McLoughlin, C and J. Luca. Lonely Outpourings or Reasoned dialogue? An Analysis of Text-based Conferencing as a Tool to Support Learning, presented at ASCILITE, Brisbane, Australia, 1999.

6. Lee, D. and P. Smargorinsky. Introduction: Constructing Meaning through Collaborative Inquiry. In: Lee, D and P. Smargorinksy (eds.), Vygotskyian Perspectives on Literacy Research: Constructing Meaning through Collaborative Inquiry, 1-18. Cambridge, United Kingdom: Cambridge University Press, 2000.

7. Vygotsky, L. Mind in Society: The Development of Higher Psychological Processes. Cambridge, MA: Harvard University Press, 1978.

8. Selfe, C. Literacy and Computers: The Complications of Teaching and Learning with Technology. NY: Modern Language Association, 1994.

9. Heath, S. Ways with Words. New York: Cambridge University Press, 1983.

10. Tharp, R., M. Note, and D. O'Donnell. Intersubjectivity, Shared Plans of Consciousness, presented at American Educational Research Association, 1991.

11. Clark, R. and R. Ivanic. The Politics of Writing. London: Routledge, 1997.

12. Garrison, D., T. Anderson and W. Archer. Critical Thinking, Cognitive Presence, and Computer Conferencing in Distance Education. The American Journal of Distance Education 15: 7-23, 2001.

13. Laurillard, D. Multimedia and the Changing Experience of the Learner. British Journal of Educational Technology 26: 179-189, 1995.

14. Ede, L. and A. Lunsford. Singular Texts/plural Authors: Perspectives on Collaborative Writing. Carbondale, IL: Southern Illinois University Press, 1990.

15. Wells, G. Dialogic Inquiry in Education. In: Lee, D and P. Smargorinksy (eds.), Vygotskyian Perspectives on Literacy Research: Constructing Meaning through Collaborative Inquiry, 51-85. Cambridge, United Kingdom: Cambridge University Press, 2000.

16. Hara, N., J. Bonk, and C. Angeli. Content Analysis of Online Discussion in an Applied Educational Psychology Course. Instructional Science 28: 115-152, 2000.

17. Ebenezer, J., F. Lugo, and A. Puvirajah. Community Building through Electronic Discussion Boards: Pre-service Teachers' Reflective Dialogues on Science Teaching. Journal of Science Education and Technology 12: 397-411, 2003. 
Electronic Spaces as an Alternative to Traditional Classroom Discussion and Writing in Secondary English Classrooms

18. Routeltap, F. and A. Eureling. Activity and Interaction of Students in an Electronic Learning Environment for Problem-based Learning. Distance Education 23: 11-32, 2002.

19. Rose, M. Comparing Productive Online Dialogue in Two Group Styles: Cooperative and Collaborative. The American Journal of Distance Education 18: 73-88, 2004.

20. Master, K. and G. Oberprieler. Encouraging Equitable Online Participation through Curriculum Articulation. Computer and Education 42: 319-332, 2004.

21. Harasim, L. Global networks: Computers and International Communication. Cambridge, MA: The MIT Press, 1994.

22. Bober, M. and V. Dennen. Intersubjectivity: Facilitating Knowledge Construction in Online Environments. Educational Media International 38: 241-250, 2001.

23. Arnseth, H. and I. Solheim. Making Sense of Shared Knowledge, presented at CSCL, Oslo, Norway, 2002.

24. Hiltz, S. The Virtual Classroom: Learning without Limits via Computer Networks. Norwood, NJ: Ablex Publishing Corporation, 1994.

25. Carlson, P. BROCA: A Computerized environment for Mediating Scientific Reasoning through Writing. Journal of Universal Computer Science 1: 571-590, 1995.

26. Geer, R. The necessity of Considering Cultural Influences in Online Collaborative Learning, presented at World conference on educational multimedia, hypermedia \& telecommunications. Tampere, Finland, 2001.

27. Hmelo-Silver, C. Analyzing Collaborative Knowledge Construction: Multiple Methods for Integrated Understanding. Computer and Education 41: 397-420, 2003.

28. Wu, A., R. Farrell, and M. Singley. Scaffolding Group Learning in a Collaborative Networked Environment, presented at CSCL, Oslo, Norway, 2002.

29. Shea, P., A. Pickett, and W. Pelz. A Follow-up Investigation of Teaching Presence in the SUNY Learning Network. The Journal of Asynchronous Learning Networks 7 (2): 61-80, 2003.

30. Scardamalia, M. and C. Bereiter. Knowledge building: Encyclopedia of Education. New York: McMillan Reference, 2002.

31. Garrison, D., T. Anderson, T. and W. Archer. Critical Thinking and Adult Education: A Conceptual Model for Developing Critical Thinking in Adult Learners. International Journal of Lifelong Education 10: 287-303, 1991.

32. Picciano, A. Beyond Student Perceptions: Issues of Interaction, Presence, and Performance in an Online Course. Journal of Asynchronous Learning Networks 6: 2002.

33. Duin, A. and C. Hansen. Reading and Writing on Computer Networks as Social Construction and Social Interaction. In: Selfe, C. and S. Hillgross (eds.), Literacy and Computers: The Complications of Teaching and Learning with Technology. New York: The Modern Language Association of America, 1994.

34. Spitzer, M. Computer Conferencing: An Emerging Technology. In Selfe, C. and G. Hillgross (eds.), Critical Perspectives on Computers and Composition Instruction, 187-200. New York: Teachers College, 1989.

35. Cecez-Kecmanoiv, D. and C. Webb. Toward a Communicative Model of Collaborative Webmediated Learning, presented at CSCL, 1999.

36. Brush, A., D. Bargeron, J. Grudin, A. Borning, and A. Gupta. Supporting Interaction Outside of Class: Anchored Discussion vs. Discussion Boards, presented at CSCL, 2002.

37. Myers, L. Approaches to Computer Writing Classrooms: Learning from Practical Experience: State University of New York Press, 1993.

38. Bonk, C., P. Medury, and T. Reynolds. Cooperative Hypermedia: The Marriage of Collaborative Writing and Mediated Environments. Computers in the Schools 10: 79-124, 1994.

39. Beach, R. and D. Lundell. Early Adolescents' Use of Computer-Mediated Communication in Writing and Reading. In: Reinking, D., L. Labbo, and R. Kieffer (eds.), Handbook of Literacy and Technology: Transformations in a Post-typographic World, 93-112. Manwha, NJ: Lawrence Erlbaum Association, 1998. 
40. Campos, M. The Hypermedia Conversation: Reflecting Upon, Building and Communicating Illdefined Arguments, presented at ED-MEDIA, Montreal, Canada, 2000.

41. Derry, S. and S. LaJoie. A Middle Camp for (Un)intelligent Instructional Computing: An Introduction. In: LaJoie, S. (ed.) Computers as Cognitive Tools, 67-98. Hillsdale, NJ: Lawrence Erlbaum Associates, 1993.

42. Dewey, J. How We Think. Boston, MA: Heath, 1933, 1991.

43. Meyer, K. Face-to-face Versus Threaded Discussions: The Role of Time and Higher-Order Thinking. Journal of Asynchronous Learning Networks 7: 2003.

44. Henri, F. Computer Conferencing and Content Analysis. In: Kaye, A. (ed.), Collaborative Learning through Computer Conferencing: The Najaden Papers, 115-136. New York: Springer, 1992.

45. Campos, M. A Constructivist Method for the Analysis of Networked Cognitive Communication and the Assessment of Collaborative Learning and Knowledge Building. Journal of Asynchronous Learning Networks 8: 2004.

46. Damon, W. and E. Phelps. Strategic Uses of Peer Learning in Children's Education. In: Ladd, T. (ed.), Peer Relationships in Children's Development, 32-54. New York: Wiley, 1989.

47. Bruner, J. Actual Minds, Possible Worlds. London: Harvard University Press, 1986.

48. Garrison, D., T. Anderson, and W. Archer. Critical Inquiry in a Text-Based Environment: Computer Conferencing in Higher Education. The Internet and Higher Education 2: 87-105, 1999.

49. Langston, M. and T. Batson. The Social Shifts Invited by Working Collaboratively on Computer, Networks: The ENFI Project. In: Handa, C. (ed.), Computers and Community: Teaching Composition in the Twenty-first Century, 140-159. Portsmouth: Boynton/Cook Publishers, 1990.

50. Wertsch, J. Vygotsky's Two Minds on the Nature of Meaning, In: Lee, D and Smargorinksy, P. (eds.), Vygotskyian Perspectives on Literacy Research: Constructing Meaning through Collaborative Inquiry, 19-30. Cambridge, United Kingdom: Cambridge University Press, 2000.

51. Myers, J. Afterword: Semiotic Assumptions in the Social Practice of Critical Literacy. In: Semali, L. (ed.), Transmediation in the Classroom: A Semiotics-based Media Literacy Framework, 133-147. New York: Peter Lang Publishing, Inc., 2002.

52. Montague, M. Computers, Cognition, and Writing Instruction. Albany, NY: State University of New York Press, 1990.

53. Teasley, S. and J. Roschelle. Constructing a Joint Problem Space: The Computer as a Tool for Sharing Knowledge. In: Lajoie, S. and Derry, S. (eds.), Computers as Cognitive Tool, 56-98. Hillsdale, NJ: Lawrence Erlbaum Associates, 1993.

54. Collins, A., J. Brown, J. and S. Newman. Cognitive Apprenticeship: Teaching the Crafts of Reading, Writing, and Mathematics. In: Rensnik, L. (ed.), Knowing, Learning, and Instruction, 453493. Hillsdale, NJ: Lawrence Erlbaum, 1989.

\section{ABOUT THE AUTHOR}

Sangmin Lee earned her Ph.D. from the Pennsylvania State University in Language and Literacy Education. Currently, she is teaching at Woosong University in Korea and is a director of Multimedia English Language Learning Center.

\section{APPENDIX: AN EXCERPT FROM A DISCUSSION THREAD}

The following is an excerpt from one of the discussion threads, and this illuminates the complex process of how the students developed and shared ideas and constructed knowledge by responding to each other through written communication and building upon others' ideas on the discussion board. Words in bold illustrate Feature Analysis 1 (sentence-type analysis); italicized words illustrate Feature Analysis 2 (interaction pattern analysis), and underlined words indicate Feature Analysis 3 (interactive phase analysis). 
Electronic Spaces as an Alternative to Traditional Classroom Discussion and Writing in Secondary English Classrooms

Table 4 Savagery Thematic Thread (Excerpt)

\begin{tabular}{|c|c|c|}
\hline No. & Messages & Feature Analysis \\
\hline 1 & $\begin{array}{l}\text { I found it very interesting that the boys were rescued due to } \\
\text { their regression to savagery. It sounds confusing, but if you } \\
\text { think about it, it makes sense: If the boys hadn't become } \\
\text { blood thirsty, they would not have wanted to get rid of the } \\
\text { little bit of society that was left (i.e. Ralph), therefore they } \\
\text { would not have hunted him. If they didn't hunt him, they } \\
\text { wouldn't have started the fire to "smoke him out" which, in } \\
\text { turn, set the entire island ablaze. If there was no blazing } \\
\text { fire, the boys wouldn't have caught the attention of the } \\
\text { passing ship. Therefore, if there was no savagery, there } \\
\text { would have been no rescue. Basically, what Ralph wanted } \\
\text { so badly (fire --> rescue) was achieved through the thing he } \\
\text { fought so desperately against (savagery and the decline of } \\
\text { their mini-civilization). I don't know if any symbolism } \\
\text { can be drawn from this sequence of events, but if there } \\
\text { is, I'd like to hear any opinions on it.... }\end{array}$ & $\begin{array}{l}\text { The first message serves to trigger others' } \\
\text { inquiry and thoughts on the issue, starts with } \\
\text { recognizing the problem, and often marks the } \\
\text { students' interest, puzzlement, and curiosity } \\
\text { (underlined). This message initiates the issue of } \\
\text { "savagery" and casts a couple of hypotheses on } \\
\text { the issue, using hypothetical/conditional } \\
\text { sentences (bold). }\end{array}$ \\
\hline 2 & $\begin{array}{l}\text { It is quite ironic that the boys were rescued do to the tribe's } \\
\text { savagery. However, if the boys had not become savage, } \\
\text { Ralph definitely would have had them keep the fire going } \\
\text { and they would have been rescued anyway. I think the fire } \\
\text { that Ralph wants is different than the fire the boys set. } \\
\text { Ralph's fire represents a civilized society, while the } \\
\text { archetype for the tribe's fire would represent destruction } \\
\text { and chaos. Basically, the tribe's fire was set to kill } \\
\text { something, and Ralph's fire was there to help the boys. The } \\
\text { ship rescues the boys from their savagery, but the ship is a } \\
\text { war ship heading out to destroy enemies. Is Golding trying } \\
\text { to say all civilizations have savagery in them, from } \\
\text { which we cannot be rescued? Or maybe people will } \\
\text { always be partially savage? }\end{array}$ & $\begin{array}{l}\text { The first underlined, italicized sentence } \\
\text { displays a response to msg. No. 1, integrating } \\
\text { with the previous idea, building on it, and } \\
\text { elaborating and developing the issue raised by } \\
\text { inferencing from the literature, using a } \\
\text { hypothesis/conditional sentence (bold). The } \\
\text { idea becomes divergent in this message, by not } \\
\text { being totally in agreement that "it would not } \\
\text { have been rescue without savagery”; thus, her } \\
\text { inferencing functioned as triggering as well. } \\
\text { The underlined sentences (questions) trigger } \\
\text { more inquiry, raising another issue of savagery } \\
\text { developed from the issue of "fire.” }\end{array}$ \\
\hline 3 & $\begin{array}{l}\text { I don't really think that Golding was trying to say that all } \\
\text { civilizations have savagery in them, from which we cannot } \\
\text { be rescued. I think that people may have savage qualities } \\
\text { inside them but it takes certain conditions for those } \\
\text { qualities to be unleashed. The boys being young and } \\
\text { immature didn't quite know how to survive on the island } \\
\text { and build a prosperous civilization until they were rescued. } \\
\text { If it would have been older more mature men it is likely } \\
\text { that they would NOT have acted in the same manner as the } \\
\text { younger boys did. The lack of life experience and } \\
\text { knowledge left the boys in a state of chaos which in return } \\
\text { caused them to act like savages. }\end{array}$ & $\begin{array}{l}\text { The underlined, italicized sentence } \\
\text { demonstrates that this message is a reply to No. } \\
\text { 2, displaying judgment-disagreement with } \\
\text { No. 2-followed by supporting argument, } \\
\text { inferencing from her common sense knowledge } \\
\text { and the book, adding another idea, age as a } \\
\text { condition of savage. } \\
\text { Hypothetical/conditional sentences were also } \\
\text { used to support her claim and draw a tentative } \\
\text { conclusion. }\end{array}$ \\
\hline 4 & $\begin{array}{l}\text { I disagree with the statement that conditions will dictate } \\
\text { what qualities are unleashed. This is not a book based on } \\
\text { situations. Golding never explained how the boys arrived at } \\
\text { the island. It is extremely vague. Golding did this to make } \\
\text { sure that a person would not confuse the meaning being } \\
\text { about a certain situation. Yes, the boys may not have been } \\
\text { mature, but they knew how to run a civilization. They knew } \\
\text { about democracy and anarchy. They chose to follow their } \\
\text { own desires when put into these situations instead of } \\
\text { looking for the common good (except for Ralph and }\end{array}$ & $\begin{array}{l}\text { The italicized statement exhibits judgment - } \\
\text { disagreement with No. 3-followed by } \\
\text { supporting argument and inferencing from the } \\
\text { literature and her knowledge about the world. }\end{array}$ \\
\hline
\end{tabular}




\begin{tabular}{|c|c|c|}
\hline & $\begin{array}{l}\text { Piggy.) Really the book is one big symbol. It takes the } \\
\text { world, and turns it into an island on which different } \\
\text { civilizations and beliefs arise through peoples desires and } \\
\text { needs. And grown men may not have done the exact same } \\
\text { things as the boys, but they do them on the scale of the } \\
\text { world. People have wars, trying to destroy the opposition. } \\
\text { The boys were used as a symbol of groups of people that } \\
\text { may want this or that. With the decay of civilization, or in } \\
\text { the book, the decay of Ralph's control, the boys turned to } \\
\text { natural instincts or hunting and meat. They became savages } \\
\text { because there were no short term affects that would profit } \\
\text { them. That is why the boys became savages. They were not } \\
\text { getting satisfaction from civilization, so they turned to } \\
\text { savagery. }\end{array}$ & $\begin{array}{l}\text { The student introduces another issue-the book } \\
\text { is a big symbol (italicized). } \\
\text { The underlined, italicized sentence shares the } \\
\text { thought with the previous messages, but also } \\
\text { adds another perspective on the issue. A } \\
\text { Hypothetical/Conditional sentence is also used } \\
\text { to agree partially with the previous message, } \\
\text { but mainly to draw her new claim, "characters } \\
\text { as symbols." } \\
\text { The underlined last sentence demonstrates a } \\
\text { tentative conclusion about her interpretation of } \\
\text { the issue. }\end{array}$ \\
\hline 5 & $\begin{array}{l}\text { Quote: "I disagree with the statement that conditions will } \\
\text { dictate what qualities are unleashed. This is not a book } \\
\text { based on situations." While I disagree with the idea that } \\
\text { Lord of the Flies is a completely situation-based book, } \\
\text { there are examples of times throughout when the } \\
\text { surrounding context of an event is very important. A good } \\
\text { example of this is the character Roger, and his seemingly } \\
\text { inherent desire to cause pain. Near the beginning of the } \\
\text { story, he throws rocks in the general direction of another } \\
\text { kid on the beach, but Roger's civility keeps him from } \\
\text { hitting the other kid. By the end of the book, Roger has } \\
\text { discovered that the new state of government on the island } \\
\text { negates accountability for one's actions, and he has no } \\
\text { problem rolling a boulder down a hill and over Piggy. } \\
\text { Behavior does not exist in a vacuum, nor is it completely } \\
\text { reliant on the nature of the individual. Situation is still } \\
\text { important in many instances. Another thing: particular } \\
\text { aspects of an individual personality are always present, } \\
\text { and always interacting. The different parts that define a } \\
\text { person (mental, physical, emotional, spiritual, and } \\
\text { etcetera,) cannot be separated and still retain their original } \\
\text { value. We should DEFINITELY compare and contrast } \\
\text { the concepts of: 1) Evil 2) Savagery 3) Survivalism. }\end{array}$ & $\begin{array}{l}\text { By repeating the sentence (italics inside } \\
\text { quotation marks) from No. 5, it shows this is a } \\
\text { direct reply to No. } 5 \text {. } \\
\text { The underlined sentence displays judgment - } \\
\text { disagreement and partial agreement with No. } \\
4 \text {-followed by a supporting example from the } \\
\text { book and adding another perspective to the } \\
\text { discussion, that is, the relationship between } \\
\text { individual personality and situations they } \\
\text { belong to (the italicized, starting with "Another } \\
\text { thing."). }\end{array}$ \\
\hline 6 & $\begin{array}{l}\text { I don't think that Golding is saying that all civilizations } \\
\text { have savagery or that people will always be capable of } \\
\text { being savages- it's really based on the person and their level } \\
\text { of understanding of consequences and effects. If it had } \\
\text { been older people stranded on the island- opposed kids- I } \\
\text { don't think that there would have been as much savagery } \\
\text { because adults would have a higher level of maturity than } \\
\text { kids. Golding focused mainly on one group of people but } \\
\text { that's not how every group of people or every civilization } \\
\text { would react if they were put in that situation. }\end{array}$ & $\begin{array}{l}\text { The italicized words begin the message with a } \\
\text { judgment-disagreement either with No. } 2 \text { or } \\
\text { No. 4.- displaying interaction with other } \\
\text { messages. } \\
\text { The italicized, underlined sentence is a } \\
\text { repetition of No. } 3 \text { or an agreement with it, } \\
\text { showing this message is built on the previous } \\
\text { ideas. } \\
\text { By using a hypothetical/conditional sentence } \\
\text { (bold) the student supports her claim. }\end{array}$ \\
\hline 7 & $\begin{array}{l}\text { I don't know if I agree with this. There is always a savage } \\
\text { side in a person; it's human nature. No matter what age or } \\
\text { what maturity level it will always be there. The civilization, } \\
\text { with its rules and institutions, in a way, keeps the savage } \\
\text { side under control. Like what was said before, the } \\
\text { civilization was decaying and therefore the boys turned to } \\
\text { their natural instincts. Even adults will turn against each } \\
\text { other because it happens every day. I'm not saying that }\end{array}$ & $\begin{array}{l}\text { The italicized sentence displays judgment-- } \\
\text { direct disagreement with No. 6-adding a new } \\
\text { idea, another reason to support the claim that } \\
\text { "all the civilization has savagery," claiming } \\
\text { that it is a human nature. } \\
\text { This is followed by inferencing from her } \\
\text { knowledge about the world, connecting it with }\end{array}$ \\
\hline
\end{tabular}


Electronic Spaces as an Alternative to Traditional Classroom Discussion and Writing in Secondary English Classrooms

\begin{tabular}{|c|c|c|}
\hline & $\begin{array}{l}\text { every person would act the same in this situation, but } \underline{I} \\
\text { don't think that Golding was trying to focus on a certain } \\
\text { group of people. I think he was showing that the boys' life } \\
\text { on the island was a microcosm of life in the world. }\end{array}$ & $\begin{array}{l}\text { the novel (underlined). } \\
\text { By asserting her disagreement (italicized) with } \\
\text { No. 6, she draws her own conclusion on the } \\
\text { issue (underlined). }\end{array}$ \\
\hline 8 & $\begin{array}{l}\text { In response to your question (Sarah P.)...I DO think } \\
\text { Golding is trying to say that all civilizations have some } \\
\text { amount of savagery in them, but I don't think it's all about } \\
\text { being rescued from this savagery. It's more or less having } \\
\text { enough strength/wisdom to keep the savagery in check and } \\
\text { under control. This is directly influenced by the strength of } \\
\text { the government that's running the civilization. For example, } \\
\text { the US government has done a great job keeping savagery } \\
\text { under control in our country over the past 200+ years. Sure, } \\
\text { we have the occasional psycho who is a murdering savage, } \\
\text { but we have a justice system whose goal it is to seek out } \\
\text { these people and punish them (with jail sentences, etc.) so } \\
\text { that the entire country doesn't go haywire. In Golding's } \\
\text { mini-civilization, there wasn't that justice system or any } \\
\text { truly powerful figure to keep the savagery in check. }\end{array}$ & $\begin{array}{l}\text { The italicized sentence displays this is a direct } \\
\text { response to No. } 2 \text {. } \\
\text { The underlined sentence demonstrates } \\
\text { synthesis of the previous two opposing } \\
\text { positions about savagery, by modifying, } \\
\text { adapting, and negotiating both positions. } \\
\text { While synthesizing, she also uses inferencing } \\
\text { from her previous knowledge about the world } \\
\text { as an example to support her claim } \\
\text { (underlined). } \\
\text { The underlined sentence is her conclusion and } \\
\text { interpretation of the book. }\end{array}$ \\
\hline 9 & $\begin{array}{l}\text { What a thoughtful series of ideas and questions! I think that } \\
\text { the meaning of this sequence of events in the book can be } \\
\text { derived even without turning the "sequence" into a symbol. } \\
\text { In other words, considering all this interpretation, what can } \\
\text { we make of this, not as a symbol for something else, but in } \\
\text { and of itself? I am also intrigued by Sarah's idea of the two } \\
\text { meanings behind the fire. This fits right in with Golding's } \\
\text { exploration of good and bad in humanity and nature in } \\
\text { general. }\end{array}$ & $\begin{array}{l}\text { No. } 9 \text { is a teacher's comment, categorized into } \\
\text { evaluation, functioning as a way of wrapping } \\
\text { up the discussion. Her message is an indirect } \\
\text { response to all the previous messages in this } \\
\text { discussion thread. By posing another question, } \\
\text { she also adds another angle to interpret the } \\
\text { issue (the underlined starting with "In other } \\
\text { words...”). } \\
\text { The italicized phrase shows that this is an } \\
\text { explicit response to No. } 2 \text { by reference of the } \\
\text { student's name. Also the underlined displays } \\
\text { her evaluation of No. } 2 \text { as a triggering message, } \\
\text { which provoked others' thoughts about the } \\
\text { issue. }\end{array}$ \\
\hline
\end{tabular}

